\title{
Faktor risiko dinamik residivisme dalam kalangan Orang DiParol (ODP): Perspektif kakitangan Parol
}

\author{
Dynamic risk factors amongst Parolees: Perspective of Parole staffs \\ Norruzeyati Che Mohd Nasir*, Noor Azizah Ahmad, Ahmad Shukri Abdul Hamid, Mariny \\ Abdul Ghani \& Mohd Alif Jasni \\ School of Applied Psychology, Social Work and Policy \\ College of Arts and Sciences \\ Universiti Utara Malaysia, Sintok, Kedah, Malaysia \\ *e-mail: zeyati@uum.edu.my
}

Received: 18 November 2019; Accepted: 21 May 2020; Published: 25 May 2020

To cite this article (APA): Che Mohd Nasir, N., Ahmad, N. A., Abdul Hamid, A. S., Abdul Ghani, M., \& Jasni, M. A. (2020). Faktor risiko dinamik residivisme dalam kalangan Orang DiParol (ODP): Perspektif kakitangan Parol. EDUCATUM Journal of Social Sciences, 6(1), 22-32. https://doi.org/10.37134/ejoss.vol6.1.3.2020

To link to this article: https://doi.org/10.37134/ejoss.vol6.1.3.2020

\begin{abstract}
Abstrak
Setiap banduan yang dikenakan hukuman pemenjaraan di atas kesalahan jenayah yang dilakukan akan kembali kepada masyarakat kecuali bagi pesalah hukuman mati. Proses integrasi semula ke dalam masyarakat umum bukanlah suatu proses yang mudah. Terdapat pelbagai cabaran yang perlu dihadapi oleh bekas banduan. Sekiranya mereka gagal dalam proses tersebut, kemungkinan bekas banduan akan terlibat semula dalam tingkah laku jenayah atau residivisme. Perkara ini menimbulkan kebimbangan terutamanya kepada agensi yang terlibat secara langsung dalam rehabilitasi banduan dan Orang DiParol (ODP). Pelaksanaan sistem parol di Malaysia pada tahun 2008 adalah antara usaha pihak kerajaan khususnya Jabatan Penjara dalam membantu ODP berjaya dalam proses integrasi semula. Kakitangan parol merupakan individu yang paling hampir dengan ODP dan bekas banduan selain keluarga. Oleh itu, kajian ini dilakukan untuk meneroka pandangan kakitangan parol tentang faktor risiko dinamik residivisme yang dihadapi oleh klien mereka. Kajian kualitatif ini melibatkan temu bual secara mendalam dengan 13 kakitangan parol Jabatan Penjara Malaysia. Hasil kajian mendapati bahawa terdapat empat faktor risiko dinamik residivisme yang perlu diberi perhatian iaitu kegagalan mendapatkan pekerjaan, stigma dan sikap masyarakat yang ragu-ragu serta tertutup terhadap bekas banduan, faktor diri sendiri dan kesediaan untuk berubah, serta penolakan keluarga. Hasil kajian ini adalah signifikan terutamanya kepada agensi kerajaan yang terlibat secara langsung dalam sistem keadilan jenayah, ahli akademik, pengamal bantuan seperti pekerja sosial, kaunselor dan pegawai psikologi penjara serta Badan Bukan Kerajaan.
\end{abstract}

Kata Kunci: Faktor risiko dinamik, residivisme, bekas banduan, Orang DiParol (ODP)

\begin{abstract}
Each prisoner who is sentenced to imprisonment for a crime committed will go back to the society except those prisoners who are sentenced for death penalty. The process of reintegration into the society is not an easy process. There are various challenges that need to be faced by the former prisoners. . If they were unable to cope with those challenges, the former prisoners might return to prison. This is of particular concern to agencies that are directly involved in the rehabilitation of prisoners and paroles (Orang DiParol; ODP). The implementation of the parole system in Malaysia in 2008 is part of the efforts by the government, especially the Prison Department, in helping the ODP to succeed in the reintegration process. Parole staffs are the closest people to the ODP and former prisoners besides their family. Therefore, this study was conducted to explore the parole staffs' views on the dynamic risk factors of residivism faced by their clients. This qualitative study involved in-depth interviews with 13 Malaysian Prison Department personnel. This study has found there are four dynamic risk factors of
\end{abstract}


recidivism that need to be addressed: unemployment, stigma and skepticism toward former prisoners, personal factors, and willingness to change as well as family rejection. The results of this study are significant to government agencies who are involved directly in the criminal justice system, academicians, practitioners such as social workers, counselors, prison psychologists and non-governmental agencies.

Keyword: Dynamic risk factors, residivisme, ex-prisoners, parolees

\section{PENDAHULUAN}

Statistik menunjukkan bilangan banduan (hukuman enam bulan ke atas) di Malaysia pada tahun 2017 ialah 54,944 orang (www.data.gov.my). Berdasarkan sumber yang sama, bilangan ini menunjukkan peningkatan berbanding tahun 2013 dengan 31,189 banduan. Setiap banduan akan kembali kepada masyarakat setelah tamat tempoh pemenjaraan kecuali banduan yang dihukum gantung sampai mati. Sistem keadilan jenayah jelas menunjukkan setiap individu yang melakukan kesalahan jenayah akan dikenakan hukuman pemenjaraan atau hukuman lain mengikut ketetapan undang-undang sesebuah negara. Pada asasnya, hukuman pemenjaraan berdasarkan tiga prinsip keadilan jenayah utama iaitu sebagai pencegahan (deterrence) kepada pesalah, menghilangkan keupayaan (incapacitation) pesalah dengan cara memberi hukuman, dan memberi rawatan atau pemulihan (rehabilitation) supaya pesalah tidak terlibat semula dalam jenayah apabila dibebaskan. Namun begitu, statistik sehingga akhir Disember 2016 yang dikeluarkan Jabatan Penjara Malaysia (2017) menunjukkan seramai 4,359 orang terlibat dalam pengulangan tingkah laku jenayah atau residivisme. Secara konsepsualnya, terma residivisme berasal daripada perkataan Latin iaitu "recidere" yang membawa maksud kembali. Menurut Esperian (2010), residivisme merujuk kepada perkembalian semula bekas banduan ke dalam penjara selepas dibebaskan ekoran penglibatan semula bekas banduan tersebut dalam tingkah laku jenayah. Terma lain yang sinonim dengan konsep residivisme dan turut digunakan dalam konteks jenayah ialah kesalahan berulang atau pengulangan jenayah.

Kewujudan masalah residivisme jenayah memberi signal bahawa sebahagian bekas banduan gagal dipulihkan atau gagal semasa proses integrasi semula ke dalam masyarakat umum. Kajian lepas mendapati integrasi semula dalam masyarakat umum selepas pemenjaraan merupakan satu tempoh yang sangat mencabar. Bekas banduan berhadapan dengan pelbagai cabaran dan isu seperti kegagalan mendapatkan pekerjaan, masalah mendapatkan tempat tinggal, masalah kesihatan fizikal yang semakin merosot, berhadapan dengan masalah kesihatan mental, distigma, kurang sokongan keluarga dan masyarakat serta kemungkinan untuk kembali terlibat dalam jenayah atau residivisme (Maruna, 2001; Laub \& Sampson, 2003; Maruna \& Toch, 2005; Uggen, Wakefield \& Western, 2005; Byrne \& Trew, 2008). Menurut Visher dan Travis (2003) dan Petersilia (2009), sesetengah bekas banduan tidak dapat menyesuaikan diri atau berintegrasi semula dengan masyarakat sehingga membawa kepada residivisme jenayah. Misalnya, kegagalan dalam mendapatkan pekerjaan boleh membawa kepada tingkah laku jenayah melibatkan harta benda. Sehubungan dengan itu, artikel ini bertujuan mengenalpasti faktor risiko dinamik dan residivisme daripada perspektif kakitangan parol.

\section{SOROTAN LITERATUR}

Proses integrasi semula bekas banduan ke dalam masyarakat merupakan satu proses yang sukar. Sekiranya mereka gagal mendepani cabaran dan masalah yang timbul, bekas banduan mungkin berisiko untuk terlibat semula dengan tingkah laku jenayah atau residivisme. Menurut Petersilia (2001), kegagalan dalam proses integrasi semula menyebabkan ramai bekas banduan ditahan selepas enam bulan dibebaskan dari penjara. Faktor penglibatan semula bekas banduan dalam jenayah boleh dikelompokkan kepada dua iaitu faktor risiko statik dan faktor risiko dinamik. Faktor risiko statik bersifat tetap atau tidak boleh diubah seperti rekod jenayah, keseriusan sejarah jenayah, rekod pemenjaraan, umur pada kemasukan pertama ke penjara atau institusi pemulihan, serta kesalahan berkaitan pengulangan jenayah. Faktor statik menyediakan maklumat penting dalam menilai risiko kepada pengulangan jenayah atau resedivisme. Faktor statik juga tidak boleh diberi intervensi kerana ianya bersifat tekal. 
Faktor risiko dinamik mempunyai sifat yang bertentangan dengan faktor risiko statik iaitu boleh berubah dari masa ke masa selepas menerima intervensi (Andrew \& Dowden, 2006; Bonta \& Wormith, 2008; Vincent, Guy \& Grisso, 2012). Sifat faktor risiko dinamik yang boleh berubah berdasarkan hasil tindak balas kepada perubahan persekitaran bekas banduan samada secara internal atau eksternal. Antara contoh faktor risiko dinamik ialah aspek psikologikal (seperti sikap, personaliti dan kognitif) serta aspek sosiologikal (seperti hubungan dan sokongan sosial orang sekeliling, pengaruh rakan sebaya, pekerjaan, penerimaan majikan, penyalahgunaan dadah dan alkohol, serta penerimaan dan stigma masyarakat). Kajian ini menumpukan kepada faktor risiko dinamik residivisme jenayah berdasarkan pengalaman kakitangan parol yang bekerja dengan bekas banduan dan ODP.

Travis (2005) mendapati majoriti bekas banduan berhadapan dengan tiga faktor risiko dinamik yang merencatkan integrasi semula bekas banduan atau ODP dalam masyarakat iaitu pekerjaan, keadaan psikologikal dan hubungan sosial dengan keluarga dan orang sekeliling. Ironinya, seseorang banduan meninggalkan penjara tanpa simpanan, tiada kelayakan untuk pekerjaan tertentu serta mempunyai kemahiran kerja yang terhad. Jabatan Koreksional California melaporkan sebanyak 60 peratus bekas banduan tidak mempunyai pekerjaan selepas setahun dibebaskan dari penjara (Crow, 2006). Sikap majikan yang tidak menunjukkan minat untuk mengaji bekas banduan merupakan antara punca mereka tidak mendapat pekerjaan.

Menurut Pager dan Quillian (2005), majikan menunjukkan minat untuk mengambil bekas banduan bekerja semasa sesi tinjauan dijalankan, namun situasi sebaliknya berlaku di alam realiti pekerjaan. Majikan sebenarnya tidak berhasrat untuk mengambil bekas banduan namun menyatakan kesediaan secara terbuka bagi mengaburi pandangan negatif mereka terhadap bekas banduan. Holzer (1996) mendapati majikan cenderung untuk mengaji pekerja kurang berpengalaman berbanding bekas banduan. Sikap tidak percaya dan tidak mahu mengambil risiko dalam kalangan majikan telah menjejaskan peluang pekerjaan kepada bekas banduan. Terdapat juga majikan yang mengambil bekas banduan sebagai pekerja namun mereka dibayar dengan upah yang rendah. Menurut Street (2001), majikan membayar upah yang rendah kerana mereka mengetahui bahawa peluang pekerjaan bekas banduan adalah terhad.

Petersilia (2001) mendapati faktor polisi pekerjaan terhadap bekas banduan turut menyumbang kepada masalah pengangguran selain daripada sikap majikan itu sendiri. Sistem sedia ada dapat mengesan rekod jenayah dan secara automatik bekas banduan tidak layak untuk pekerjaan tertentu khususnya yang memerlukan kelayakan profesional dan berdaftar (Petersilia, 2001). Sekali individu melakukan kesalahan jenayah, selama-lamanya individu tersebut akan dilabel sebagai bekas banduan dan mereka turut berhadapan dengan kehilangan hak-hak sivil (Seiter \& Kadela, 2003). Masalah sukar mendapatkan pekerjaan ekoran sikap majikan, rekod jenayah dan polisi berkaitan menjadi antara penghalang utama kejayaan integrasi semula. Niven dan Olagundaye (2002) mendapati bekas banduan yang mendapat pekerjaan yang stabil selepas dibebaskan mempunyai risiko yang rendah untuk mengulangi kesalahan jenayah dahulu.

Selain pekerjaan, cabaran lain yang dihadapi oleh bekas banduan ialah kegagalan mendapatkan tempat tinggal yang selesa (Crow, 2006). Tempat tinggal merupakan keperluan asas kepada setiap manusia. Bradley dan rakan-rakan (2001) percaya bahawa tempat tinggal merupakan elemen utama dalam memastikan kejayaan proses integrasi semula bekas banduan. Bekas banduan yang gagal mendapatkan tempat tinggal berkemungkinan akan menjadi gelandangan dan berisiko kepada tingkah laku jenayah (Crow, 2006). Kajian oleh Joseph Rowntree Foundation (1996) di empat buah penjara mendapati dua pertiga bekas banduan yang tiada tempat tinggal melakukan kesalahan jenayah dalam tempoh setahun selepas dibebaskan. Masalah tempat tinggal bertambah rumit bagi bekas banduan yang tiada keluarga atau tiada tempat tinggal sebelum dipenjarakan. Kajian Burt dan rakan-rakan (2002), 49 peratus individu yang pernah dikenakan hukuman penjara tiada tempat tinggal yang tetap sebaliknya menjadikan kaki lima, lorong-lorong dan bawah jambatan sebagai tempat berteduh.

Menurut Belenko (2006), tanpa tempat tinggal yang baik bekas banduan sukar untuk mendapatkan kerja dan berisiko dalam aktiviti penyalahgunaan bahan. Bekas banduan yang tinggal di jalanan sukar mendapatkan pekerjaan kerana tidak mempunyai alamat tetap atau tiada nombor telefon untuk dihubungi oleh majikan (Rodriguez \& Brown, 2003). Selain itu, upah yang rendah diterima oleh bekas banduan menyebabkan mereka tidak mampu menyewa rumah (Bradley et al. 2001). Masalah tempat tinggal bekas banduan berkait juga dengan polisi perumahan kerajaan yang tidak melayakkan mereka memohon program perumahan (Wodahl, 2006). Selain itu, stigma masyarakat terhadap bekas banduan 
menyebabkan mereka sukar untuk menyewa rumah apabila status sebagai bekas banduan diketahui oleh tuan rumah.

Cabaran lain yang turut dialami oleh bekas banduan ialah stigma dan kurang sokongan sosial daripada keluarga dan masyarakat sekeliling. Penerimaan keluarga dan masyarakat memainkan peranan yang penting dalam menentukan kejayaan integrasi semula bekas banduan (Visher \& Travis, 2003). Sokongan daripada ahli keluarga mampu menaikkan semangat bekas banduan untuk memulakan kehidupan yang baru. Keluarga bukan sahaja berperanan dalam memberi sokongan moral malah dapat menyediakan perlindungan, makanan, dan bantuan kewangan sebaik sahaja dibebaskan. Namun kepulangan bekas banduan ke pangkuan keluarga selalunya diikuti dengan perasaan yang bercampur baur iaitu seronok, teruja, takut dan bimbang (Shapiro \& Schwartz, 2001). Evans (2006) mendapati kepulangan bekas banduan kebiasaannya menimbulkan perasaan marah dan geram dalam kalangan keluarga. Keadaan ini berkait dengan bebanan kewangan dan emosi yang terpaksa ditanggung oleh keluarga sepanjang tempoh pemenjaraan. Sumber kewangan mungkin terjejas sekiranya ahli keluarga yang bertanggung jawab mencari nafkah dipenjarakan. Keluarga juga terpaksa menanggung malu dan berhadapan dengan pandangan negatif masyarakat setiap masa.

Stigma daripada masyarakat terhadap golongan banduan turut memberi kesan kepada kejayaan reintegrasi (Moore, Stuewig \& Tangney, 2016; Grossi, 2017; Moore et al., 2018). Stigma masyarakat kepada bekas banduan sudah sebati dan sukar untuk diubah. Masyarakat cenderung untuk memberikan persepsi yang negatif walaupun bekas banduan telah menunjukkan tingkah laku yang baik. Hal ini disebabkan masyarakat sering disogokkan dengan berita-berita yang menakutkan melibatkan bekas banduan yang boleh menimbulkan sikap bias dan prejudis. Usaha untuk mengubah stigma ini bukan mudah kerana ia merupakan kerangka mental yang sudah terbentuk hasil daripada pembelajaran dan perubahan sosial. Masyarakat memainkan peranan yang penting dalam proses ini kerana sejauh mana penerimaan mereka terhadap bekas banduan dapat mengurangkan risiko residivisme.

\section{KAEDAH KAJIAN}

Kajian ini ialah kajian penerokaan yang menggunakan rekabentuk kualitatif. Kajian penerokaan atau exploratory adalah signifikan apabila pengkaji mempunyai sedikit maklumat atau pengetahuan saintifik tentang tentang sesuatu situasi, proses, aktiviti atau kumpulan (Stebbins, 2001). Objektif kajian ini ialah mengenal pasti faktor risiko dinamik yang boleh menyumbang kepada residivisme jenayah dalam kalangan bekas banduan daripada perspektif kakitangan parol. Responden kajian terdiri daripada 13 kakitangan parol daripada Jabatan Penjara Malaysia. Bilangan responden seramai 13 orang adalah mencukupi dalam kajian kualitatif. Menurut Dworkin (2012), 5 hingga 50 responden adalah mencukupi bagi penyelidik yang menggunakan rekabentuk kualitatif yang menekankan penjelasan secara mendalam dengan menggunakan pendekatan temu bual. Selain itu, kajian ini turut mengambil kira kesediaan pegawai parol untuk terlibat sebagai responden. Pemilihan responden adalah secara bertujuan iaitu kakitangan parol yang terdiri daripada mereka yang bekerja di Pejabat Parol di negeri Selangor dan Wilayah Persekutuan Kuala Lumpur, serta sedia bekerjasama dalam memberi maklumat tentang pengalaman mereka mengurus, memantau dan mengawasi bekas banduan. Kakitangan parol merupakan golongan yang paling hampir dengan bekas banduan. Seramai 13 kakitangan bersetuju untuk ditemubual dan mereka terdiri daripada pelbagai jawatan iaitu pegawai parol, inspektor, penolong pegawai parol, penyelia Rumah Perantaraan, warden dan korperal. Kebenaran menjalankan proses pengumpulan data bagi kajian ini adalah berdasarkan kelulusan daripada Bahagian Dasar Kepenjaraan, Jabatan Penjara Malaysia.

Teknik penggumpulan data yang digunakan dalam kajian ini ialah teknik temu bual separa berstruktur. Teknik ini memerlukan pengkaji menyediakan dahulu senarai soalan yang akan ditanya kepada responden. Semasa proses membina soalan kualitatif, penyelidik telah mendapatkan pandangan pakar kajian kualitatif termasuklah pandangan semua ahli dalam kajian ini yang menggunakan pendekatan kualitatif semasa peringkat Doktor Falsafah. Perbincangan ini bertujuan mengesahkan soalan yang dibina dan memastikan kredibiliti soalan. Penyelidikan kualitatif menekankan aspek kredibiliti antaranya melalui rich and thick deskripsi verbatim yang diperolehi daripada temu bual. Soalan lain mungkin timbul semasa sesi temu bual bergantung kepada maklumat yang diberikan oleh responden. 
Menurut Cohen dan Crabtree (2006), kelebihan temu bual separa berstruktur ialah menyediakan set arahan yang jelas kepada pengkaji dan menjadikan data kualitatif lebih reliable melalui soalan-soalan yang timbul semasa sesi berlangsung. Data yang diperoleh melalui teknik ini dipercayai mampu menonjolkan perkara yang tersimpan dalam fikiran responden, serta amat berkesan untuk meninjau persepsi, pemikiran, sikap, nilai dan pendapat seseorang. Temu bual dilakukan berpandukan objektif kajian iaitu mengenal pasti cabaran-cabaran yang dihadapi oleh bekas banduan dalam proses reintegrasi. Sesi temu bual berlangsung selama 30 hingga 45 minit dan melibatkan satu sesi.

Data yang diperoleh daripada kajian lapangan dianalisis secara tematik bagi mengenal pasti faktor risiko dinamik terhadap residivisme jenayah. Analisis tematik merupakan salah satu kaedah dalam menganalisis data yang diperolehi daripada kajian kualitatif. Menurut Braun dan Clarke (2006), analisis tematik melibatkan proses mengenal pasti, menganalisis, menyusun, menghuraikan dan melaporkan tema data lapangan. Data yang diperolehi daripada hasil temu bual diasingkan dan dikelompokkannya mengikut persamaan dan perbezaan tema. Hanya satu tema yang akan dianalisis dalam satu-satu masa agar seluruh perhatian dapat ditumpukan kepadanya tanpa dipengaruhi oleh maklumat yang tidak berkaitan. Hal ini penting untuk mengelakkan pengkaji membuat rumusan awal tentang aspek yang dikaji dan mengelak bias.

\section{HASIL KAJIAN}

Bahagian ini membincangkan hasil kajian berkaitan faktor risiko dinamik residivisme dalam kalangan bekas banduan daripada perspektif kakitangan parol. Berdasarkan analisis tematik yang dilakukan terhadap data mentah, terdapat empat tema yang dapat menjelaskan isu yang dikaji. Tema tersebut ialah:

\section{Gagal mendapatkan pekerjaan}

Hasil temu bual dengan kakitangan parol di Jabatan Penjara Malaysia menunjukkan isu pekerjaan selepas pemenjaraan atau parol adalah antara cabaran utama yang dihadapi oleh bekas banduan atau ODP. Kesukaran mendapatkan pekerjaan berkait dengan rekod jenayah atau dadah, persepsi majikan terhadap bekas banduan, sikap bekas banduan yang memilih pekerjaan dan pekerjaan menawarkan pendapatan yang rendah. Kegagalan mendapatkan pekerjaan meningkatkan risiko resividisme jenayah dan penglibatan dalam penyalahgunaan bahan. Menurut P08:

Pengalaman saya di penjara dulu, bila kita interview dia (bekas banduan), kenapa terlibat balik dengan jenayah? Dia akan bagi alasan, saya kat luar tak dapat kerja, so bila takda kerja saya tak boleh nak survive. Seminggu saya keluar, tak ada duit saya akan mencuri, buat macam-macam jenayah untuk dapatkan duit secara mudah...majikan tak bagi peluang. So alasan tu yang dia bagi pada kita. (P08)

Responden memberitahu bahawa bekas banduan gagal mendapatkan pekerjaan disebabkan persepsi negatif sebahagian majikan, mengambil sikap berhati-hati terhadap bekas banduan serta keengganan majikan menerima bekas banduan yang pernah menjadi penagih dadah. P01 dan P04 berkongsi pengalaman semasa membantu bekas banduan mendapatkan pekerjaan namun kebanyakan majikan tidak menerima mereka untuk bekerja.

Kebanyakanya memang tak berapa nak terima lah diorang ni. Mungkin diorang ingat diorang ni jahat sampai ke mati ke apa ke. (P01)

Itu masalah utama sekarang. Bila kita terima dia keluar parol, kita ada produk. Diorang nak berubah. Tapi penerimaan majikan tu tak boleh...Kita nak kalau boleh majikan boleh bagi peluang pada ODP untuk bekerja. (P04)

Berdasarkan temu bual, keengganan majikan mengambil bekas banduan terutamanya mereka yang pernah terlibat dengan dadah kerana bimbang akan menimbulkan masalah di tempat kerja dan 
pengalaman menguruskan mereka. Menurut P10 dan P08, terdapat majikan yang fobia dan tidak mempertimbangkan ODP yang mempunyai kes dadah untuk bekerja.

Saya tengok bukan semua majikan yang boleh terima ODP-ODP kita untuk bekerja dekat diorang...terutamanya kalau ODP tu kes dadah. Diorang (majikan) fobia. Jadi sebenarnya agak memberi cabaran la kepada pegawai parol untuk nak approach majikan nak minta ambil kita punya ODP. Bukan mudah la. Ada yang sanggup terima dan banyaknya yang tak dapat terimalah. (P10)

Bila dia kata, yang kes dadah saya tak mahu,...Kalau yang kes-kes lain dia kata dia boleh pertimbangkan lagilah. So banyak yang menolak... Sebab dia kata mungkin pada dia diorang ni mungkin tak boleh bertahan lama la. Dia tak nak ambil risiko. (P08)

Pernah saya jumpa majikan, susahlah nak jaga diorang salah, saya banyak kerja nak buat. (P04)

Responden turut berkongsi pengalaman tentang majikan yang tidak mahu menanggung risiko kerugian dalam perniagaan akibat mengambil bekas banduan bekerja terutama kes dadah. Terdapat bekas banduan atau ODP kes dadah yang diambil bekerja dan menjadikan tempat kerja sebagai tempat berkumpul rakan-rakan sehingga menganggu perniagaan mereka.

Majikan ni dia tengok membawa masalah, maknanya dia panggil pula geng-geng kumpul pula kat situ. Jadi dia tak nak business tu terganggu disebabkan ni. Risiko. Jadi, nak selamat biasanya diorang tak naklah yang kes dadah ni. Kalau boleh kes lain yang boleh bagi komitmen dalam pekerjaan. (P10)

\title{
Mentaliti masyarakat yang tidak menerima, berfikiran tertutup, streotaip dan ragu-ragu dengan bekas banduan
}

Temu bual yang dilakukan dengan kakitangan parol mendapati faktor risiko dinamik residivisme jenayah termasuklah penolakan masyarakat terhadap bekas banduan. Kebanyakan masyarakat masih mempunyai sikap stigma, streotaip dan ragu-ragu dengan kesungguhan bekas banduan untuk berubah. Walaupun negara sedang bergerak menjadi negara maju, namun mentaliti masyarakat terhadap bekas banduan masih lagi mundur sepertimana yang dijelaskan oleh P02.

\begin{abstract}
Masyarakat kita ni dia tak boleh lari daripada benda tu, streotaip terhadap banduan ...negara ni akan ke negara maju tapi belum sampai tahap tu lagi. Penerimaan orang terutama orang Melayu, dia punya pemikiran tu masih orang cakap tak macam negara maju. Tak kisah ...masyarakat kita ni masih takuttakut. Masyrakat kita ni berbeza dengan orang putih. Orang putih ni masuk jail sepuluh kali pon dia boleh terima tak ada masalah. Sebab diorang punya pemikiran dia tinggi kan. Macam kita ni masih ada kolot dia tu lagi. (PO2)
\end{abstract}

Kejayaan integrasi semula bekas banduan dalam masyarakat bergantung kepada penerimaan masyarakat. P09 menegaskan masyarakat perlu bertanggungjawab terhadap ahli-ahli mereka dengan cara memberi sokongan sosial dan membuang stigma terhadap bekas banduan. Peranan memulihkan bekas banduan bukan terletak kepada pihak berkuasa semata-mata.

Masyarakat dia kena menerima balik ahli masyarakat dia. Dia tidak boleh serahkan kepada pihak berkuasa untuk memantau ahli masyarakat dia...Masyarakat kena memainkan peranan. Sampai bila dia nak serahkan kepada pihak berkuasa, kepada pihak polis, pihak penjara, pihak AADK, tapi diorang tak memainkan peranan. Diorang kena bagi sokongan...Kalau diorang tak buang stigma banduan tak guna, sampai bila pun banduan tidak akan berjaya...Selagi masyarakat tak terbuka, kita ambil pesalah daripada masyarakat selepas kita pulihkan di dalam penjara kita kembalikan pada masyarakat tapi masyarakat tak berfungsi, tak berperanan...So maknanya sia-sia saja program pemulihan di dalam kalau masyarakat tak mau bantu, selain daripada individu itu sendiri. (P09)

Kita seorang tak boleh pulihkan banduan. Kita memang tak boleh, kita memang kita tak boleh nak pulihkan diorang. Tapi kalau masyarakat support, beri kerjasama, maknanya beri dia peluang, InshaaAllah boleh". (P07) 
P6 berkongsi pengalaman tentang kegusaran yang timbul dalam kalangan masyarakat apabila bekas banduan kembali ke kampung halaman. P07 pula berpandangan bekas banduan tidak menimbulkan masalah sekiranya masyarakat menerima mereka dengan baik.

Cabaran utamanya stigma masyarakat...bekas banduan ni...stigma masyarakat, yang tinggi... dia terasa contohnya dia rasa...kadang-kadang masyarakat kita tengok, masyarakat kampung, tengok balik, ala dia ni dah balik dah. (P06)

Cabarannya sebenarnya masyarakat. Diorang ni pada saya takde masalah. Kes apa pun pada saya sebenarnya masyarakat yang perlu menerima diorang ni. (P07)

Penolakan atau persepsi negatif masyarakat lebih ketara kepada bekas banduan kes dadah sepertimana yang dimaklumkan oleh P05 dan P12.

Masyarakat ni dah memang...first je kalau kata dadah je, dah terus think negatif. (P05)

Banduan penagih ni memang persepsi macam tu lah. Di mana-mana pun, kalau balik kampung pun mulalah, 'dia dah balik tu.' Tu persepsi masyarakat. Dia susah nak percaya. Susah nak percaya dengan penagih dadah ni. (P12)

Penolakan masyarakat terhadap bekas banduan menyebabkan mereka tidak yakin untuk kembali kepada masyarakat. Perasaan bimbang dengan penerimaan masyarakat menyebabkan bekas banduan lebih selesa mencari kawan-kawan lama sebaik dibebaskan. Situasi ini meningkatkan kemungkinan bekas banduan terlibat semula dengan jenayah apabila berjumpa kawan lama seperti yang dikongsi oleh P02.

Dia keluar pada pintu penjara. Ha apa aku nak buat ni, macam mana masyarakat nak terima aku ni, apa aku nak buat, kalau aku balik rumah, keluarga aku susah nak terima. Aku jumpa kawan aku dulu la. Jumpa kawan pastu tak tau nak buat apa. Jadi untuk terjebak balik tu tinggi peratus dia. (P02)

Reaksi masyarakat yang tidak menerima bekas banduan mungkin berdasarkan sikap bekas banduan terutamannya kes dadah yang tidak berubah dan terlibat dengan tingkah laku jenayah. Misalnya, P05 menjelaskan:

Atitude diorang (bekas banduan). Sebab kita dah biasa, dah lali. Kalau contoh la dalam kawasan tu memang orang dah kenal dengan dia tu, dia dadah, kalau dia hisap dadah dia tak kacau orang takpe, ini dia mencurinya, menyamunnya. Itu masyarakat yang tak suka tu. (P05)

\section{Faktor diri-sendiri dan kesediaan untuk berubah}

Hasil temu bual bersama kakitangan parol mendapati faktor diri sendiri yang tidak ingin berubah turut meningkatkan risiko residivisme jenayah. Kakitangan parol, P03 meluahkan perasaan bimbang tentang kemungkinan ODP terjebak semula dengan jenayah.

Nampak dah ada yang beberapa orang yang saya tak berapa nak percaya. Dia boleh mengulang semua ni...jadi bila duduk di luar, ada beberapa percent (bekas banduan) yang buat perkara tak elok, dia buat balik. (P03)

Apabila selesai tempoh parol, bekas banduan mungkin berhadapan dengan pelbagai sumber tekanan yang boleh mendedahkan mereka dengan tingkah laku pengulangan jenayah. P03 memberitahu walaupun bekas banduan tidak mengulangi perbuatan jenayah namun kehidupan selepas pemenjaraan yang diselubungi banyak tekanan menyebabkan mereka tidak selesa. Menurut P06, bekas banduan perlu mempunyai jati diri yang kuat dalam menghadapi cabaran selepas dibebaskan dari penjara. Banyak kes di mana bekas banduan gagal berhadapan dengan tekanan terutama tekanan kewangan akibat kegagalan mendapatkan pekerjaan. Apabila bekas banduan didatangi pusher dadah, mereka selalunya terjebak semula dengan aktiviti jual beli dadah.

Hasil temu bual dengan kakitangan parol mendapati ODP atau bekas banduan perlu menunjukkan yang mereka betul-betul ingin berubah dan tidak menyalahkan sepenuhnya kepada keluarga dan masyarakat. 
Responden percaya masyarakat boleh menerima bekas banduan jika mereka menunjukkan kesungguhan untuk tidak lagi terlibat dengan jenayah. Oleh itu, kakitangan parol sentiasa memberi semangat supaya mereka melakukan perubahan dengan kemahuan sendiri.

Dalam hidup ni kita pesan kat diorang (ODP dan bekas banduan), nak menyalahkan masyarakat totally bahawa tidak terima, tidak boleh. Macam kita pergi tampar orang pastu kita minta maaf, orang takkan terima kita dalam masa yang singkat. Kita kena akui benda tu. Terpaksa la bagitau dia nak menyalahkan masyarakat tak boleh. Kita buat silap pada keluarga tiba-tiba besok kita minta maaf, kita dah pecahkan barang dan mengungut keluarga, besok kita minta maaf. Adakah dalam masa yang singkat orang boleh maafkan kita? So kena terap pada diri...diri kita sendirilah yang akan mengubah bentuk diri kita. (P11)

Kita tak boleh nak salahkan masyarakat sekeliling. Macam diorang ni...dia nakkan 100\% daripada masyarakat...tapi dia boleh bagi 10\% je pada masyarakat. Apa-apa pun kena diri dia dulu sebab masyarakat tu hanya boleh terima dia kalau ada perubahan pada diri dia. Sebab kita tak boleh salahkan masyarakat, kalau dia tak boleh buktikan, buktikan yang dia dah boleh jadi somebody... Masyarakat pun takde masalah terima diorang. (P05)

Bagi saya pokoknya ODP sendiri, banduan tu. Walaupun dapat sokongan daripada keluarga, masyarakat, komuniti, NGO, tapi pokok utama, diri tu, ODP tu sendiri. Kalau ada rasa hati nak berubah, jadi baik, akan menjadi. Kalau diri sendiri tak ada rasa nak berubah, takda nak baik, walaupun dapat sokongan daripada luar pun tak jadi juga, ODP tu sendiri. Kita bagi nasihat ke, bagi tunjuk ajar ke, bagi panduan ke, pokoknya ODP tu sendiri, banduan tu. Kalau dia rasa nak berubah, rasa nak jadi baik. (P08)

Sikap malas berusaha, mudah mengalah, menyalahkan orang lain, berfikiran negatif dan terlalu bergantung kepada orang lain turut meningkatkan risiko pengulangan tingkah laku jenayah. Menurut P4, sikap bekas banduan yang malas berusaha merumitkan kejayaan integrasi semula.

Sikap dioranglah...diorang bila kita bantu diorang, tapi dia masih dengan sikap malas nak bekerja. Kita bantu, kita usahakan cari majikan. Tapi sikap diorang la. Ada malas, ada suka melengahlengahkan masa, macam tu lah. (P04)

Saya pernah tanya banduan, betul ke takde kerja di luar? Itu bergantung pada diri. Nak, tak nak. Kalau nak berubah InshaaAllah rezeki tu ada. Mungkin la ada juga kalau pergi minta (kerja) tak dapat, mungkin...Tu la, kekuatan dalaman tu juga. (P11)

Ada setengah-setengah tu seolah-olah macam kita nak kena ajar satu-satu, "awak daripada rumah, turun pukul berapa, naik bas nombor ni kemudian tukar bas nombor ni, sampai sini berjalan ... haa detail macam tu. Dia macam tak boleh nak buat sendiri langsung. (P08)

Responden kajian turut berkongsi pandangan bahawa bekas banduan atau ODP mempunyai pemikiran negatif yang tinggi dan perasaan rendah diri. Perasaan tersebut menyebabkan mereka menjauhkan diri daripada masyarakat.

Bila dia status banduan, dia sendiri rasa rendah diri. (P03)

Kadang-kadang diorang punya negative thinking terlampau tinggi...Diorang akan fikir, lepas ni keluarga dah tak sayang mereka...Saya ni dah masuk dalam penjara saya ni jahat. Saya tak baik macam orang kat luar. (P05)

\section{Penolakan keluarga}

Faktor risiko dinamik residivisme bekas banduan yang turut dikemukakan oleh kakitangan parol ialah penolakan daripada keluarga. Penolakan keluarga lebih ketara bagi bekas banduan yang dipenjarakan akibat kes dadah berbanding kes jenayah yang lain. P04 berkongsi pandangan berikut: 
Biasanya kes dadahlah yang keluarga susah nak terima. Kalau kes jenayah ni keluarga terima... kes dadah bagi ancaman pada keluarga. (P04)

Sikap ahli keluarga yang memandang rendah kepada bekas banduan yang menunjukkan tingkah laku ingin berubah turut mendorong kepada residivisme jenayah. P04 menceritakan bahawa ada bekas banduan yang ingin mengubah sikap negatif dan tingkah laku mereka ke arah yang lebih baik, namun keluarga merendah-rendahkan usaha mereka untuk berubah.

Bila dia nak ubah sikap biasanya orang salah ni sikap dia negatif banyak. Bila dia masuk penjara, bila dia keluar dia nak berubah. Bila dia ubah kepada positif, pandangan keluarga kadang-kadang merendah-rendahkan dia, alah kau ni nak berubah jadi alim la. (P04)

Keenganan keluarga mengambil berat bekas banduan menyebabkan ada bekas banduan yang mencari rakan sebaya sebagai sumber sokongan sosial seperti yang dikongsi oleh P07.

Kadang-kadang family tak ambil tahu, dia bebas pun, ahh...aku cari kawan la family aku pun bukan terima aku. (P07)

\section{PERBINCANGAN, IMPLIKASI DAN CADANGAN}

Kajian ini merupakan kajian eksplorasi tentang faktor risiko dinamik residivisme dalam kalangan bekas banduan daripada perspektif kakitangan parol. Temu bual secara mendalam telah dijalankan dengan 13 kakitangan parol yang terdiri daripada pelbagai jawatan. Kajian melibatkan temu bual dengan kakitangan parol di Pejabat Parol Hulu Langat dan di Rumah Perantaraan Wilayah Persekutuan Kuala Lumpur. Hasil kajian menunjukkan terdapat empat faKtor risiko dinamik residivisme yang utama dalam kalangan ODP iaitu 1) kegagalan mendapatkan pekerjaan, 2) mentaliti masyarakat yang tidak menerima, berfikiran tertutup, streotaip, dan ragu-ragu dengan bekas banduan atau ODP, 3) faktor diri sendiri untuk berubah, dan 4) penolakan keluarga. Faktor yang menyebabkan bekas banduan sukar atau gagal mendapatkan pekerjaan ialah rekod jenayah, persepsi majikan terhadap bekas banduan, majikan mengambil sikap berhati-hati terhadap bekas banduan serta keengganan majikan menerima bekas banduan penagih dadah, sikap bekas banduan itu sendiri yang memilih pekerjaan dan pekerjaan menawarkan pendapatan yang rendah. Hasil dapatan ini adalah selari dengan kajian lepas seperti Travis (2005), Crow (2006), Pager dan Quillian (2005), Street (2001) dan Petersilia (2001). Travis (2005) menekankan bahawa pekerjaan menjadi antara faktor risiko dinamik utama yang merencatkan proses integrasi semula bekas banduan ke dalam masyarakat umum. Dapatan kajian Crow (2006) menunjukkan majoriti bekas banduan tiada pekerjaan selepas setahun dibebaskan dari penjara. Terdapat juga majikan yang membayar upah yang rendah kepada bekas banduan kerana mereka mengetahui bahawa bekas banduan mempunyai peluang kerja yang terhad. Selain itu, polisi yang membolehkan majikan mengesan rekod jenayah bekas banduan turut mengurangkan peluang pekerjaan terhadap golongan tersebut (Petersilia, 2001).

Seterusnya, mentaliti dan stigma masyarakat terhadap bekas banduan turut menjadi faktor risiko dinamik residivisme. Stigma dan persepsi negatif kepada bekas banduan sudah sebati dan sukar untuk diubah walaupun bekas banduan menunjukkan keperibadian dan tingkah laku yang baik. Sikap masyarakat yang negatif kepada bekas banduan mungkin hasil daripada pembelajaran dan perubahan sosial tentang kumpulan marginal tersebut. Selain masyarakat, peranan keluarga juga penting dalam memastikan kejayaan proses integrasi semula (Visher \& Travis, 2003). Namun, kajian lepas menunjukkan kepulangan bekas banduan ke pangkuan keluarga menimbulkan pelbagai reaksi emosi (Evans, 2006) dan ada keluarga yang tidak menerima ahli keluarga mereka sendiri. Faktor risiko dinamik residivisme terakhir ialah keadaan diri bekas banduan yang tidak mahu berubah dan mempunyai sikap malas berusaha, mudah mengalah, menyalahkan orang lain, berfikiran negatif serta terlalu bergantung kepada orang lain. Sikap yang ditunjukkan oleh bekas banduan mungkin impak daripada pemenjaraan ke atas kesejahteraan psikologikal mereka. Menurut Reed (2015), pemenjaraan boleh membawa kepada tekanan perasaan, takut, serta kecelaruan atau kemurungan kepada penghuni- 
penghuninya. Kegagalan membendung impak psikologikal ini meningkatkan risiko kesukaran untuk beradaptasi dengan persekitaran baharu.

Implikasi langsung kajian ini ialah kepada agensi yang terlibat dengan bekas banduan dan ODP iaitu Jabatan Penjara Malaysia, kakitangan parol serta pengamal bantuan seperti pekerja sosial, kaunselor dan ahli psikologi. Hasil kajian memberi input dan pengetahuan kepada kakitangan parol dan pengamal bantuan dalam mentaksir keperluan banduan yang akan dibebaskan dari penjara atau ODP yang masih dalam pengawasan parol. Selain itu, hasil kajian ini membantu pihak penjara atau pejabat parol dalam merangka polisi dan program yang signifikan dalam memastikan kejayaan integrasi semula bekas banduan. Dalam konteks praktis intervensi, pengamal bantuan boleh menetili pendekatan dan strategi intervensi yang menekankan perspektif sistem ekologi dan melakukan intervensi pada pelbagai peringkat sistem iaitu mikro, mezzo dan makro. Walaupun hasil kajian ini dapat menjelaskan tentang faktor risiko dinamik residivisme ODP dari perspektif kakitangan parol, namun terdapat beberapa perkara yang perlu dipertimbangkan terutamanya dalam konteks metodologi kajian. Kajian pada masa akan datang perlu menggunakan responden kajian yang lebih ramai dan pelbagai seperti bekas banduan atau ODP, keluarga, majikan dan anggota masyarakat serta menggunakan pendekatan kuantitatif.

\section{PENGHARGAAN}

Terima kasih kepada Kementerian Pendidikan Malaysia dalam menyediakan Dana Pembudayaan Penyelidikan (RAGS) (Kod S/O: 13279) bagi menjalankan kajian tentang Model Reintegrasi Sosial Bersepadu Bekas Banduan dan Orang DiParol (ODP) di Rumah Perantaraan Jabatan Penjara Malaysia.

\section{RUJUKAN}

Andrews, D.A., \& Dowden, C. (2006). Risk principle in case classification in correctional treatment: A metaanalytic investigation. International Journal of Offender Therapy and Comparative Criminology, 50 (1), $88-100$.

Belenko, S. (2006). Assessing released inmates for substance-abuse-related service needs. Crime \& Delinquency, 52(1), 94-113.

Bonta, J., \& Wormith, S. (2008). Risk and need assessment. Dalam G. McIvor, \& P. Raynor (Eds.), Developments in social work with offenders, (pp. 131-152). London: Jessica Kingsley.

Bradley, K. H., Michael Oliver R. B., Richardson, N. C. \& Slayter, E. M. (2001). No place like home: Housing and the ex-prisoner. Community Resources for Justice. [Online] Available www.crjustice.org/hmbrief.htm.

Braun, V., Clarke, V. (2006). Using thematic analysis in psychology. Qualitative Research in Psychology, 3: 77101.

Burt, M. R., Pollack, D., Sosland, K. S., Drapa, E., Greenwalt, K., \& Sharkey, P. T. (2002). Evaluation of continuums of care for homeless people. Washington, DC: Urban Institute.

Byrne, C. F., \& Trew, K. J. (2008). Pathways through crime: The development of crime and desistance in the accounts of men and women offenders. The Howard Journal of Criminal Justice, 47: 238-258. doi:10.1111/j.1468-2311.2008.00520.x.

Cohen, D. \& Crabtree, B. (2006). Qualitative research guidelines project. Robert Wood Johnson Foundation. http://www.qualres.org/index.html

Crow, I. (2006) Resettling prisoners: A review. Sheffield: University of Sheffield.

Dworkin, S.L. (2012). Sample size policy for qualitative studies using in-depth interviews. Archives of Sexual Behavior, 41: 1319-1320.

Esperian, J. (2010). Effect of prison education programs on recidivism. Journal of Correctional Education, 61(4), 316-334.

Evans, J. (2006). AHS incarcerated women's initiative: Bending the curve: The state of our children. Paper presented at the Southeast Correctional Facility, Windsor, VT, by the Vermont Children's Aid Society.

Grossi, L.M. (2017). Sexual offenders, violent offenders, and community reentry: Challenges and treatment considerations. Aggression and Violent Behavior, 34: 59-67.

Holzer, H.J. (1996). What employers want: Job prospects for less-educated workers. New York, NY: Russell Sage Foundation. 
http://www.data.gov.my/data/ms_MY/dataset/statistik-kemasukan-banduan-sabitan-mengikut-

klasifikasi-pesalah/resource/e84d7d07-2db3-4af6-aad8-5ed6b2ced828

Jabatan Penjara Malaysia (2017). Jumlah banduan pengulanglaku jenayah, 2000-2016. Diakses pada 25 Mei 2017 dari Unit Sistem maklumat: http://www.prison.gov.my/portal/page/portal/biru/kepenjaraan

Joseph Rowntree Foundation. (1996). The housing needs of ex-prisoners. New York, NY: Joseph Rowntree Foundation.

Laub, J., \& Sampson, R. (2003). Shared beginnings, divergent lives: Delinquent boys to age 70. Cambridge, MA: Harvard University Press.

Maruna, S. (2001). Making good: How ex-convicts reform and rebuild their lives. Washington, DC: American Psychological Association Books.

Maruna, S., \& Toch, H. (2005). The impact of imprisonment on the desistance process. Dalam J. Travis \& C. Visher (Eds.), Prisoner reentry and crime in America (pp. 139-178). New York, NY: Cambridge University Press.

Moore, K.E., Milam, K.C., Folk, J.B., \& Tangney, J.P. (2018). Self-stigma among criminal offenders: Risk and protective factors. Stigma and Health, 3(3): 241-252

Moore, K.E., Stuewig, J.B., \& Tangney, J.P. (2016). The effect of stigma on criminal offenders' functioning: A longitudinal mediational model. Deviant Behavior, 37(2): 196-218.

Niven, S., \& Olagundoye, J. (2002). Jobs and homes: a survey of prisoners nearing release. London: Home Office Research, Development and Statistics Directorate.

Pager, D., \& Quillian, L. (2005). Walking the talk? What employers say versus what they do? American Sociological Review, 70 (3). pp. $355-380$.

Petersilia, J. (2001). Prisoner reentry: Public safety and reintegration challenges. The Prison Journal, 81(3): 360375.

Petersilia, J. (2003). When prisoners come home: Parole and prisoner reentry. New York: Oxford University Press.

Rodriguez, N., \& Brown, B. (2003). Preventing homelessness among people leaving prison. Vera Institute of Justice. [Online]. Available: http://www.vera.org/publication_pdf/209_407.pdf.

Seiter, R., \& Kadela, K. (2003). Prisoner reentry: What works, what does not, and what is promising. Crime \& Delinquency, 49(3), 360-388.

Shapiro, C., \& Schwartz, M. (2001). Coming home: Building on family connections. Corrections Management Quarterly, 5(3), 52-61.

Stebbins, R.A. (2001). Qualitative research methods: Exploratory research in the social sciences. Thousand Oaks, CA: SAGE Publications.

Travis, J. (2005). But they all come back: Facing the challenges of prisoner reentry. Washington, DC: The Urban Institute Press.

Uggen, C., Wakefield, S., \& Western, B. (2005). Work and family perspectives on reentry. Dalam J. Travis, \& C. Visher (Eds.), Prisoner reentry and crime in America (pp. 209-243). New York, NY: Cambridge University Press.

Vincent, G., Guy, L., \& Grisso, T. (2012) Risk assessment in juvenile justice: A guidebook for implementation, National Youth Screening and Assessment Project for Models for Change.

Visher, C., \& Travis, J. (2003). Transition from prison to community: Understanding individual pathways. Annual Review of Sociology, 29, 89-113.

Wodahl, E. J. (2006). The challenges of prisoner reentry from a rural perspective. Western Criminology Review, $7(2), 32-47$. 